\title{
Ecotone Dynamics and Stability from Soil Scientific Point of View
}

\author{
Theodore Danso Marfo ${ }^{1}$, Rahul Datta ${ }^{1, *}$ (D), Shamina Imran Pathan ${ }^{2}$ and Valerie Vranová ${ }^{1}$ \\ 1 Department of Geology and Soil Science, Mendel University in Brno, Zemědělská 1, 61300 Brno, \\ Czech Republic; rastheodore2002@yahoo.com (T.D.M.); valerie.vranova@mendelu.cz (V.V.) \\ 2 Department of Department of Agriculture, Food, Environment and Forestry, University of Florence, Piazzale \\ delle Cascine 28, 50144 Florence, Italy; shamina.pathan@unifi.it \\ * Correspondence: rahulmedcure@gmail.com
}

Received: 24 February 2019; Accepted: 30 March 2019; Published: 3 April 2019

check for updates

\begin{abstract}
Transitional areas between two or more different biomes-ecotones-are clearly visible due to the sudden changes in vegetation structures and patterns. However, much is still unknown about the crucial soil factors that control such vegetational changes across ecotones and how different soil properties vary across ecotones. In this study, we try to understand the spatial variation in soil properties across a clearly defined ecotone from a forest stand to meadow field at the Training Forest Enterprise (T.F.E), Masaryk Forest Křtiny, Czechia. Thirteen sampling sites were selected: six in the forest region, six in the meadow and one in the ecotone zone between forest and meadow. Soil samples were taken at $5 \mathrm{~cm}$ below the soil surface once every month from April to November. All the collected soil samples were examined for minimal air capacity, actual and potential soil reaction and maximum capillary water. The results showed a pattern of soil acidity decreasing from the forest stand towards the meadow field but that increased sharply at the ecotone zone. The water holding capacity showed a decreasing trend approaching the ecotone zone from the meadow region and markedly decreased from the meadow site closest to the ecotone zone. The minimum air capacity showed an increasing trend from the forest region but suddenly declined at the ecotone region.
\end{abstract}

Keywords: ecotone; biomes; maximum capillary water; actual and potential soil reaction

\section{Introduction}

An edge is a zone where two or more biomes meet as a result of a sudden change in soil properties due to anthropogenic activities or a change in climatic condition [1], whereas ecotones, being defined as a transition zone of vegetation between adjacent ecological systems, are places where two different communities meet and integrate [2-4]. Ecotones are useful for studying the connection between soil and vegetation independently from other soil forming components like parent material, time, climate, etc. [5-7]. Due to persisting human activities, lowland forests in Central Europe tend to be fragmented $[8,9]$ and surrounded by arable lands, grasslands and meadows, resulting in several ecotones dominated by herbaceous communities [10]. There has been a longstanding assertion that ecotones are territories of high species diversity [11], supporting Leopold's theory which states that there is both higher diversity and density of organisms at ecotone regions than the adjacent biomes they lie between [10]. Josef Zeithaml et al.'s [12,13] research "Earthworm assemblages in an ecotone between forest and arable field and their relations with soil properties" concluded that forest edges might play a positive role in the maintenance of earthworm species richness in agroecosystems.

Soil properties across forest ecotones and meadows are controlled by many factors that operate at different spatial scales. Factors such as landform, topography, temperature, and vegetation play important roles in configuring soil properties [14-20]. Soil temperature and moisture are two key factors 
directly determining many chemical and biological processes in soil, such as enzymatic degradation of biomolecule in soil, nutrient and water uptake by roots [21-24]. Above all, soil moisture can control plant distribution and community composition at high altitudes across ecotones $[5,25,26]$. Hence, knowledge of spatial and temporal variability of soil properties is crucial to understanding the impact of climate change on ecosystems such as ecotones.

This study analyses how soil properties like soil reaction, maximum capillary capacity and minimum air capacity vary across a forest-meadow ecotone at the Krrtiny study plot of the Training Forest Enterprise (T.F.E), Masaryk Forest Krrtiny, Czechia. These three soil properties were chosen for this study because together they paint a picture of the soil's ability to support plant growth and, in effect, other fauna as well. Among the many soil properties, soil $\mathrm{pH}$ stands out as one of the most essential, as it influences nutrient uptake to a large extent. The soil's ability to retain water for plant use and the soil's aeration ability when all capillary pores are filled are crucial, hence we chose to also measure maximum capillary capacity and minimum air capacity. The study focuses on how these soil properties tend to change across the ecotone area so as to explain edge effects from a soil science perspective.

Field and lab analyses of soil profiles were done to evaluate the role of these variables in controlling the position of the forest-meadow ecotone at this site. Knowledge of the spatial variations of key soil properties that have a direct effect on both flora and fauna survival will bring clarity to the ecotone concept from a soil science point of view.

\section{Materials and Methods}

\subsection{Sampling and Processing}

For this study, thirteen sampling sites were selected (six sites in the meadow region, six sites in the forest region and a central site termed 'the ecotone site') at the Krrtiny experimental site of the Training Forest Enterprise Masaryk Forest Křtiny, Czech Republic (GPS 49.2948289N, 16.7503464E). Sampling was done once a month during March to November 2015 at $5 \mathrm{~cm}$ depth from the Ah horizon. The forest region of the experimental site was predominantly a middle-aged mixed stand of Oak (Quercus) and Beech (Fagus) (33 years, oak 60\%, beech 40\%, 460-470 m a.s.1., 49.2948289N, 16.7503464E). The soils in both regions (forest and meadow) were inceptisols [27]. Soil was sieved through a 5-mm sieve and stored in a refrigerator at $4{ }^{\circ} \mathrm{C}$ [28]. The dry matter content of each soil sample was calculated before the start of the experiments, and the moisture content of soil was maintained at $25 \%$.

\subsection{Chemical Analysis}

Actual soil reaction and potential soil reaction were analysed according to the International Organization for Standardization (ISO 10390:2005) methodology; soil was homogenised with a $2 \mathrm{~mm}$ sieve and refrigerated at 5 degrees centigrade, and $\mathrm{pH}$ tested using the pHE-04 Glass Combination $\mathrm{pH}$ Electrode. Soil $\mathrm{pH}$ was measured both in water and $0.01 \mathrm{M} \mathrm{CaCl}_{2}$, two common methods [29]. Maximum capillary water capacity and minimum air capacity were analysed according to Novak [30] with minor modifications: soil samples collected using the Kopecky's rings [31] were firstly weighed fresh, saturated for $24 \mathrm{~h}$, given sufficient time to allow for excess moisture to drain and weighed at this state, then dried to constant weight (105 degrees centigrade for $12 \mathrm{~h}$ ). The calculations below were then used to determine the maximum capillary capacity and the minimum air capacity

\section{Maximum capillary water capacity $(\Theta M K K)$}

$\Theta M K K=m M K K-m d / V \Theta \mathrm{MKK}$-maximum capillary water capacity $(\%)$ $m M K K$-weight of the artificially saturated sample after 2 hours of draining off moisture $(\mathrm{g})$ $m d$-weight of the sample dried to the constant moisture (g) $V$-sample volume in Kopecky's soil sample ring $\left(\mathrm{cm}^{3}\right)$

\section{Minimum air capacity (AMKK)}




\section{Bulk density}

$\rho d=c-a / V$

$\rho d$-bulk density $\left(\mathrm{g} \cdot \mathrm{cm}^{3}\right)$

$c$-weight of Kopecky's ring with lids and soil sample dried to constant weight (g)

$a$-weight of Kopecky's soil sample ring with lids (g)

$V$-volume of the Kopecky's soil sample ring $\left(\mathrm{cm}^{3}\right)$

\section{Specific weight}

$\rho s=m 1 /(m 1+m 2)-m 3$

$\rho s$-specific weight $\left(\mathrm{g} \cdot \mathrm{cm}^{3}\right)$

$m 1$-weight of soil sample dried to constant weight $(\mathrm{g})$

$m 2$ - weight of pycnometer with distilled water (g)

$m 3$ - weight of pycnometer with the sample after boiling and distilled water (g)

\section{Porosity}

$P=\rho s-\rho d / \rho s \times 100$

$P$-porosity (\%)

$\rho s$-specific weight $\left(\mathrm{g} \cdot \mathrm{cm}^{3}\right)$

$\rho d$-bulk density $\left(\mathrm{g} \cdot \mathrm{cm}^{3}\right)$

\section{Minimum air capacity}

$A M K K=P-\Theta M K K$

$A M K K$-minimum air capacity $(\%)$

$P$-porosity $(\%)$

$\Theta M K K$-maximum capillary water capacity $(\%)$

\subsection{Statistical Analysis}

Two-way analysis of variance (ANOVA, site $\times$ time) was used to check any significant effect of site, time and their interaction (site $\times$ time) on the variability of the data. Further, multiple pairwise comparisons of means were done by Tukey's HSD (honestly significant difference) test at $p<0.05$ level of significance to analyse individual effects of each factor. Statistical data processing was done using Past 3.1.

\section{Results}

Two-way ANOVA results showed that sampling site and time and their interactions significantly affected soil properties (Table 1). The actual soil reaction ( $\mathrm{pH}$ ) ranged from 6.49 to 4.47 (Table 2). The highest value was measured in the meadow region during the month of April, while the lowest value was recorded in the forest during September (Table 2). Pairwise comparison showed that actual soil $\mathrm{pH}$ was significantly decreasing from the meadow sites towards the forest sites throughout the year (Table 2).

The potential soil reaction $(\mathrm{pH})$ ranged from 2.86 to 4.12 . The highest value was measured in the meadow region during September, while the lowest value was recorded in the forest region during July. Pairwise comparison showed that potential soil $\mathrm{pH}$ also followed the same trend as actual soil reaction and significantly decreased from meadow sites towards the forest sites throughout the year (Table 2).

Maximum capillary water ranged from 24.35 to 45.35 . The highest value was measured in the meadow region during November, while the lowest value was recorded in the ecotone region during 
April (Table 2). Pairwise comparison showed that sampling site and seasonality (time) significantly influenced the maximum capillary water.

An increasing trend was observed for the minimum air capacity from the meadow region towards the ecotone and forest for April, August and October (Table 2). In the other months, values fluctuated from one region to another, and there were significant differences in minimum air capacity among regions throughout the year.

Table 1. Main effects due to sampling time, sampling site and their interaction on the variability of selected chemical variables. Values are F-values (F-stat) from two-dimensional ANOVA (Time $\times$ Site) with the corresponding P level and statistical significance. $\left({ }^{*}=p<0.05,{ }^{* *}=p<0.01,{ }^{* * *}=p<0.001\right)$.

\begin{tabular}{cccccc}
\hline Factor & df & $\begin{array}{c}\text { Actual Soil } \\
\text { Reaction }\end{array}$ & $\begin{array}{c}\text { Potential Soil } \\
\text { Reaction }\end{array}$ & $\begin{array}{c}\text { Maximum } \\
\text { Capillary Water }\end{array}$ & $\begin{array}{c}\text { Minimum Air } \\
\text { Capacity }\end{array}$ \\
\hline Time & 7 & $4.98^{* * *}$ & $6.33^{* * *}$ & $19.29^{* * *}$ & $41.71^{* * *}$ \\
\hline Site & 2 & $72.30^{* * *}$ & $246.20^{* * *}$ & $178.30^{* * *}$ & $267.60^{* * *}$ \\
\hline Time $\times$ Site & 14 & $3.70^{* * *}$ & $6.40^{* * *}$ & $5.33^{* * *}$ & $22.25^{* * *}$ \\
\hline
\end{tabular}

Table 2. Variation of selected soil properties across the forest meadow ecotone throughout the year. Data represent means and errors of three replicates. Significant differences within each time are indicated in the bold script (in the column) (one-way ANOVA followed by Tukey post hoc test, $p<0.05$ ).

\begin{tabular}{|c|c|c|c|c|c|c|c|c|c|}
\hline & & \multicolumn{8}{|c|}{ Time } \\
\hline & & April & May & June & July & August & Sept & Oct & Nov \\
\hline \multirow{3}{*}{$\begin{array}{l}\text { Actual Soil } \\
\text { Reaction }\end{array}$} & Meadow & $6.49 \pm 0.26$ & $6.11 \pm 0.07$ & $5.67 \pm 0.1$ & $6.38 \pm 0.11$ & $6.07 \pm 0.04$ & $6.04 \pm 0.16$ & $6.39 \pm 0.05$ & $6.28 \pm 0.13$ \\
\hline & Ecotone & $5.18 \pm 0.07$ & $5.91 \pm 0.1$ & $5.57 \pm 0.06$ & $5.49 \pm 0.09$ & $5.32 \pm 0.12$ & $5.19 \pm 0.04$ & $5.21 \pm 0.05$ & $5.73 \pm 0.04$ \\
\hline & Forest & $5.54 \pm 0.26$ & $5.34 \pm 0.17$ & $5.29 \pm 0.07$ & $5.03 \pm 0.11$ & $5.39 \pm 0.16$ & $4.47 \pm 0.42$ & $5.78 \pm 0.15$ & $5.54 \pm 0.26$ \\
\hline \multirow{3}{*}{$\begin{array}{l}\text { Potential Soil } \\
\text { Reaction }\end{array}$} & Meadow & $3.92 \pm 0.06$ & $3.88 \pm 0.13$ & $3.96 \pm 0.16$ & $3.49 \pm 0.02$ & $3.97 \pm 0.13$ & $4.12 \pm 0.14$ & $3.9 \pm 0.03$ & $4.22 \pm 0.11$ \\
\hline & Ecotone & $3.42 \pm 0.1$ & $3.06 \pm 0.03$ & $3.1 \pm 0.05$ & $3.51 \pm 0.15$ & $3.46 \pm 0.13$ & $3.06 \pm 0.03$ & $3.54 \pm 0.07$ & $3.2 \pm 0.05$ \\
\hline & Forest & $3.39 \pm 0.05$ & $2.97 \pm 0.05$ & $3.02 \pm 0.06$ & $2.86 \pm 0.05$ & $2.92 \pm 0.06$ & $2.99 \pm 0.07$ & $3.2 \pm 0.02$ & $3.26 \pm 0.03$ \\
\hline \multirow{3}{*}{$\begin{array}{c}\text { Maximum } \\
\text { Capillary Water }\end{array}$} & Meadow & $33.67 \pm 1.13$ & $40.16 \pm 0.85$ & $40 \pm 1.02$ & $44.39 \pm 1.85$ & $43.12 \pm 1.44$ & $35.83 \pm 1.21$ & $42.68 \pm 0.67$ & $45.35 \pm 1.76$ \\
\hline & Ecotone & $24.35 \pm 0.25$ & $30.05 \pm 0.04$ & $24.06 \pm 0.5$ & $32.59 \pm 0.56$ & $33.11 \pm 0.44$ & $29.18 \pm 0.2$ & $32.36 \pm 1.15$ & $32.92 \pm 0.19$ \\
\hline & Forest & $28.23 \pm 1.53$ & $25.06 \pm 1.26$ & $30.52 \pm 1.75$ & $36.65 \pm 1.31$ & $34.62 \pm 1.46$ & $34.82 \pm 1.51$ & $28.59 \pm 1.1$ & $31.47 \pm 2.66$ \\
\hline \multirow{3}{*}{$\begin{array}{l}\text { Minimum Air } \\
\text { Capacity }\end{array}$} & Meadow & $14.69 \pm 1.01$ & $12.63 \pm 0.78$ & $8.1 \pm 0.42$ & $14.37 \pm 0.52$ & $9.39 \pm 1.76$ & $10.64 \pm 0.33$ & $9.32 \pm 0.54$ & $6.43 \pm 0.98$ \\
\hline & Ecotone & $22.25 \pm 0.34$ & $25.32 \pm 0.49$ & $4.14 \pm 0.29$ & $19.02 \pm 0.52$ & $19.02 \pm 0.16$ & $17.32 \pm 1.21$ & $21.91 \pm 0.77$ & $24.49 \pm 1.57$ \\
\hline & Forest & $27.52 \pm 0.68$ & $23.63 \pm 1.14$ & $18.67 \pm 1.24$ & $13.22 \pm 0.62$ & $21.99 \pm 2.64$ & $15.17 \pm 0.76$ & $26.58 \pm 1.08$ & $31.02 \pm 1.2$ \\
\hline
\end{tabular}

\section{Discussion}

This study observed the effect of sampling site and time on variations in soil reaction, maximum capillary capacity and minimum air capacity across a clearly defined forest-meadow ecotone. The soil in the forest region was more acidic than in the meadow region, as expected due to confirmations by several previous of research studies [32,33]. However, the trend in the soil $\mathrm{pH}$ variations approaching the ecotone site is worth noting, as it depicts the edge effect. In fact, from the forest region, there was a gradual decrease in acidity, but it increased at the ecotone site and decreased again towards the meadow region.

The maximum capillary water capacity in the forest region was lower than in the meadow area, indicating a moderate to strong water holding capacity [34]. There was a decreasing trend from the meadow region towards the ecotone site (where it markedly decreased) and a gradual increase towards the forest region. This trend can be attributed to the edge effect.

Although the minimum air capacity was higher in the forest than at the meadow, the values measured for both biomes fell within the limits that can support plant growth [34]. Again, the edge effect can be seen in the trend where the values suddenly decline or increase at the ecotone site.

The observations for the maximum capillary capacity and the minimum air capacity are indirectly supported by Rhoades's research [35], which revealed significantly higher bulk density in the soils of forest openings compared to surrounding forests. 
The noticeable trend where the soil properties measured changing abruptly as the ecotone zone is approached confirms the existence of edge effect, thus supporting Rhoades [35] and Munroe's ecotone research studies [33], that showed sharp changes in physical and chemical soil properties as well as in biologically-controlled soil processes at the transition region of a grassland-forest ecotone.

\section{Conclusion}

The highlight of this research is the changing trend of the measured soil properties as the ecotone site is approached. Soil acidity, as expected, decreased from the forest region towards the meadow but upon approaching the ecotone site there was a sudden increase. This same trend was evident in the maximum capillary capacity (linked with the minimum air capacity), which saw a decreasing trend from the meadow, but decreased remarkably at the ecotone site, which can be attributed to possible compaction as a result of frequent research activities.

Although most ecotone studies have mainly been focused on vegetation changes, this research was more focused on soil properties such as soil reaction, maximum capillary capacity and minimum air capacity. However, the outcome of this study supports the popular assertion that ecotones tend to exhibit special ecological traits that are different from the adjoining communities, thus often allowing them to be home for special species that may not be found in the adjoining biomes.

We conclude that ecotonal or edge effects appear to influence the soil properties of ecotone zones, evidencing the complex nature of the physical and biotic processes that combine to control the spread of plants across ecotones.

Author Contributions: T.D.M., work on Conceptualization, methodology, validation, formal analysis; investigation, resources; writing — original draft preparation. R.D. and S.I.P. work on writing — review and editing, software and data curation. V.V. were project administration, funding acquisition, visualization, supervision.

Funding: This work was supported by Technology agency of the Czech Republic (TAČR), project no. TA04020888, "Contactless monitoring and spatio-temporally modelling variability of selected different soil characteristics"

Conflicts of Interest: The authors declare no conflict of interest.

\section{References}

1. Gosz, J.R. Fundamental ecological characteristics of landscape boundaries. In Ecotones; Springer: Boston, MA, USA, 1991; pp. 8-30.

2. Hennenberg, K.J.; Goetze, D.; Kouamé, L.; Orthmann, B.; Porembski, S. Border and ecotone detection by vegetation composition along forest-savanna transects in Ivory Coast. J. Veg. Sci. 2005, 16, 301-310. [CrossRef]

3. Van der Maarel, E. Ecotones and ecoclines are different. J. Veg. Sci. 1990, 1, 135-138. [CrossRef]

4. Walker, S.; Wilson, J.B.; Steel, J.B.; Rapson, G.L.; Smith, B.; King, W.M.; Cottam, Y.H. Properties of ecotones: Evidence from five ecotones objectively determined from a coastal vegetation gradient. J. Veg. Sci. 2003, 14, 579-590. [CrossRef]

5. Jenny, H. Factors of Soil Formation: A System of Quantitative Pedology; Courier Corporation: North Chelmsford, MA, USA, 1994.

6. Kohli, A.; Schmerbeck, J. Soil properties in forest-grassland ecotone: The case of Shola-grasslands in the Palni Hills. In Land-use Related Biodiversity in India; p. 14. Available online: http:/ / www.palanihills.net/uploads /1/ 7/1/3/17138260/kohli_etal_2010_soil_of_shola-grasslands_in_palni_hills.pdf (accessed on 10 March 2019).

7. Murphy, S. Soil Properties of Forest-Grassland Ecotones in Southwest Yukon. B.Sc. Thesis, Queen's University, Kingston, ON, Canada, 2012.

8. Cetin, M.; Zeren, I.; Sevik, H.; Cakir, C.; Akpinar, H. A study on the determination of the natural park's sustainable tourism potential. Environ. Monit. Assess. 2018, 190, 167. [CrossRef] [PubMed]

9. Honnay, O.; Jacquemyn, H.; Bossuyt, B.; Hermy, M. Forest fragmentation effects on patch occupancy and population viability of herbaceous plant species. New Phytol. 2005, 166, 723-736. [CrossRef] [PubMed]

10. Bossuyt, B.; Hermy, M.; Deckers, J. Migration of herbaceous plant species across ancient-recent forest ecotones in central Belgium. J. Ecol. 1999, 87, 629-638. [CrossRef] 
11. Gilmore, D.W. Ecosystem management-A needs driven, resource-use philosophy. For. Chron. 1997, 73, 560-564. [CrossRef]

12. Zeithaml, J.; Pižl, V.; Sklenička, P. Earthworm assemblages in an ecotone between forest and arable field and their relations with soil properties. Pesqui. Agropecuária Bras. 2009, 44, 922-926. [CrossRef]

13. Yadav, G.; Datta, R.; Imran Pathan, S.; Lal, R.; Meena, R.; Babu, S.; Das, A.; Bhowmik, S.; Datta, M.; Saha, P. Effects of Conservation Tillage and Nutrient Management Practices on Soil Fertility and Productivity of Rice (Oryza sativa L.)-Rice System in North Eastern Region of India. Sustainability 2017, 9, 1816. [CrossRef]

14. Davidson, E.A. Spatial covariation of soil organic carbon, clay content, and drainage class at a regional scale. Landsc. Ecol. 1995, 10, 349-362. [CrossRef]

15. Goderya, F.S. Field scale variations in soil properties for spatially variable control: A review. J. Soil Contam. 1998, 7, 243-264. [CrossRef]

16. Groffman, P.M.; Hanson, G.C.; Kiviat, E.; Stevens, G. Variation in microbial biomass and activity in four different wetland types. Soil Sci. Soc. Am. J. 1996, 60, 622-629. [CrossRef]

17. Johnson, L.C.; Shaver, G.R.; Cades, D.H.; Rastetter, E.; Nadelhoffer, K.; Giblin, A.; Laundre, J.; Stanley, A. Plant carbon-nutrient interactions control $\mathrm{CO}_{2}$ exchange in Alaskan wet sedge tundra ecosystems. Ecology 2000, 81, 453-469.

18. Sinowski, W.; Auerswald, K. Using relief parameters in a discriminant analysis to stratify geological areas with different spatial variability of soil properties. Geoderma 1999, 89, 113-128. [CrossRef]

19. Molaei, A.; Lakzian, A.; Datta, R.; Haghnia, G.; Astaraei, A.; Rasouli-Sadaghiani, M.; Ceccherini, M.T. Impact of chlortetracycline and sulfapyridine antibiotics on soil enzyme activities. Int. Agrophys. 2017, 31, 499-505. [CrossRef]

20. Molaei, A.; Lakzian, A.; Haghnia, G.; Astaraei, A.; Rasouli-Sadaghiani, M.; Ceccherini, M.T.; Datta, R. Assessment of some cultural experimental methods to study the effects of antibiotics on microbial activities in a soil: An incubation study. PLoS ONE 2017, 12, e0180663. [CrossRef] [PubMed]

21. Kirschbaum, M.U. The temperature dependence of soil organic matter decomposition, and the effect of global warming on soil organic C storage. Soil Biol. Biochem. 1995, 27, 753-760. [CrossRef]

22. Datta, R.; Kelkar, A.; Baraniya, D.; Molaei, A.; Moulick, A.; Meena, R.; Formanek, P. Enzymatic degradation of lignin in soil: A review. Sustainability 2017, 9, 1163. [CrossRef]

23. Van Cleve, K.; Yarie, J. Interaction of temperature, moisture, and soil chemistry in controlling nutrient cycling and ecosystem development in the taiga of Alaska. In Forest Ecosystems in the Alaskan Taiga; Springer: New York, NY, USA, 1986; pp. 160-189.

24. Voroney, R.P. The soil habitat. In Soil Microbiology, Ecology and Biochemistry; Elsevier: Amsterdam, The Netherlands, 2007; pp. 25-49.

25. Breshears, D.D.; Barnes, F.J. Interrelationships between plant functional types and soil moisture heterogeneity for semiarid landscapes within the grassland/forest continuum: A unified conceptual model. Landsc. Ecol. 1999, 14, 465-478. [CrossRef]

26. Datta, R.; Anand, S.; Moulick, A.; Baraniya, D.; Pathan, S.I.; Rejsek, K.; Vranova, V.; Sharma, M.; Sharma, D.; Kelkar, A.; et al. How enzymes are adsorbed on soil solid phase and factors limiting its activity: A Review. Int. Agrophys. 2017, 31, 287-302. [CrossRef]

27. Palmer, A. Inceptisols. In Encyclopedia of Soils in the Environment, Reference Module in Earth Systems and Environmental Sciences; 2005; pp. 248-254. Available online: https:/ /doi.org/10.1016/B0-12-348530-4/00027-8 (accessed on 3 March 2019).

28. Datta, R.; Vranová, V.; Pavelka, M.; Rejšek, K.; Formánek, P. Effect of soil sieving on respiration induced by low-molecular-weight substrates. Int. Agrophys. 2014, 28, 119-124. [CrossRef]

29. ISO 10390:2005. Soil Quality—Determination of pH. 2005. Available online: https://www.iso.org/standard/ 40879.html (accessed on 10 March 2019).

30. Winters, A.; Harland, M.B. Preparation of Soil Samples for Pipette Analysis. 1930. Available online: https: / / dl.sciencesocieties.org/publications/aj/abstracts /22/9/AJ0220090771?access=0\&view=pdf (accessed on 15 February 2019).

31. Folegatti, M.V.; do Brasil, R.P.C.; Blanco, F.F. Sampling equipament for soil bulk density determination tested in a Kandiudalfic Eutrudox and a Typic Hapludox. Sci. Agric. 2001, 58, 833-838. [CrossRef]

32. Marfo, T.D.; Resjek, K.; Vranova, V. Spatial variations in soil properties across ecotones: A short review. Bull. Geogr. Phys. Geogr. Ser. 2018, 14, 71-77. [CrossRef] 
33. Munroe, J.S. Physical, chemical, and thermal properties of soils across a forest-meadow ecotone in the Uinta Mountains, Northeastern Utah, USA. Arct. Antarct. Alp. Res. 2012, 44, 95-106. [CrossRef]

34. Rejšek, K. Forest pedology-exercises. Skriptum. Mzlu V Brně 1999. Available online: https:/ / www.worldcat. org/title/lesnicka-pedologie-cviceni/oclc/41831909 (accessed on 10 February 2019).

35. Rhoades, C.C.; Miller, S.P.; Skinner, D.L. Forest vegetation and soil patterns across glade-forest ecotones in the Knobs region of northeastern Kentucky, USA. Am. Midl. Nat. 2005, 154, 1-11. [CrossRef] 